\title{
Bacillus schlegelii, a New Species of Thermophilic, Facultatively Chemolithoautotrophic Bacterium Oxidizing Molecular Hydrogen
}

\author{
By ANITA SCHENK AND MICHEL ARAGNO \\ Laboratoire de Microbiologie, Institut de Botanique, \\ Université de Neuchâtel, CH-2000 Neuchâtel, Switzerland
}

(Received 10 April 1979)

\begin{abstract}
A thermophilic, facultatively chemolithoautotrophic bacterium oxidizing molecular hydrogen has been isolated. It formed round, terminal endospores and had a multilayered cell wall. Although growth rates were highest under autotrophic conditions, certain organic chemicals, including short-chain fatty acids, some amino acids, 1-propanol and phenol, could serve as sole carbon and energy sources; ammonium ions, urea and L-asparagine could serve as sole nitrogen sources. The hydrogenase was membrane-bound and did not reduce NAD(P). The guanine+cytosine content of its DNA was 67 to $68 \mathrm{~mol} \%$. Based on its morphological and biochemical features, the organism belongs to Bacillus, but differs from any of the previously described species attributed to this genus. It is therefore proposed as constituting a new species, Bacillus schlegelii, named after the German microbiologist H. G. Schlegel. The type strain of B. schlegelii, strain MA48, has been deposited with the German Collection of Microorganisms, Göttingen, under the accession number DSM 2000.
\end{abstract}

\section{INTRODUCTION}

Aerobic, hydrogen-oxidizing bacteria form a physiological group comprising bacteria from various taxa (Davis et al., 1969, 1970; Aragno et al., 1977; Walther-Mauruschat et al., 1977). Mesophilic, spore-forming, hydrogen-oxidizing bacteria, among them Bacillus pycnoticus, were isolated by Ruhland $(1922,1924)$ and Grohmann (1924). These strains were subsequently lost; besides, the descriptions by Grohmann (1924) suggest that some of them at least could have been mixed cultures. Further attempts to isolate mesophilic, spore-forming, hydrogen-oxidizing bacteria have so far failed (Wilde, 1962; Eberhardt, 1965). Thermophilic, hydrogen-oxidizing bacteria that have been described to date belong to the genera Pseudomonas and Flavobacterium (Aragno \& Schlegel, 1980). However, numerous strains of a thermophilic, endospore-forming, hydrogen-oxidizing bacterium were isolated by Aragno (1978). These organisms were long, straight, peritrichously flagellated rods, with terminal round endospores swelling the sporangium, their Gramreaction was variable and they grew optimally at $70{ }^{\circ} \mathrm{C}$; they were considered to belong to the genus Bacillus. This paper is concerned with the characterization and taxonomy of two representative strains of this bacterium, MA48 and MA51. 


\section{METHODS}

Organisms. The two strains of thermophilic, endospore-forming, hydrogen-oxidizing bacteria studied here, MA48 and MA51 (DSM 2000 and DSM 2001, respectively), were isolated from the surface layer of the sediment of a small eutrophic lake, Le Loclat, near St-Blaise, Neuchâtel, Switzerland. The enrichment and isolation procedures used have been described previously (Aragno, 1978).

The following strains were used for comparison: mesophilic strains of Bacillus sphaericus, labelled NRS1691, NRS1692, NRS1693, NRS1694, NRS1695 and NRS1696, and the type strain of B. acidocaldarius (ATCC 27009), received from Dr R. E. Gordon, Rutgers University, New Brunswick, U.S.A.; thermophilic strains of B. sphaericus, labelled S55-67, S56-67, S58-67, S60-67, S62-67, S64-67, S66-67, E1-65, H14-66 and L54-66, received from Dr F. Hollaus, Zuckerforschungs-Institut, Fuchsenbigl, Austria; B. thermoruber strain BT/2, received from Dr R. Craveri, Università degli Studi, Milano, Italy; Aquaspirillum autotrophicum type strain (DSM 732, ATCC 29984), obtained from the Culture Collection of the Institut de Botanique, Université de Neuchâtel, Switzerland.

Media and growth conditions. The basal mineral medium, after Schlegel et al. (1961), contained: $4.5 \mathrm{~g}$ $\mathrm{Na}_{2} \mathrm{HPO}_{4} .2 \mathrm{H}_{2} \mathrm{O}, 1.5 \mathrm{~g} \mathrm{KH}_{2} \mathrm{PO}_{4}, 1 \mathrm{~g} \mathrm{NH}_{4} \mathrm{Cl}, 0.2 \mathrm{~g} \mathrm{MgSO}_{4} .7 \mathrm{H}_{2} \mathrm{O}, 0.01 \mathrm{~g} \mathrm{CaCl}_{2} .2 \mathrm{H}_{2} \mathrm{O}, 0.005 \mathrm{~g}$ ferric ammonium citrate and $5 \mathrm{ml}$ trace element solution SL6 [solution SL4 of Pfennig \& Lippert (1966) minus EDTA and iron salt] in $1000 \mathrm{ml}$ double-distilled water. The final $\mathrm{pH}$ was about $7 \cdot 1$.

For autotrophic growth, $\mathrm{NaHCO}_{3}\left(0.5 \mathrm{~g}^{-1}\right)$ was added; cultures were then incubated under $0.05 \mathrm{~atm}$ $\mathrm{O}_{2} / 0 \cdot 1$ atm $\mathrm{CO}_{2} / 0 \cdot 45 \mathrm{~atm} \mathrm{H}_{2}$ (partial pressures measured at laboratory temperature) in desiccators, without agitation. Reduced pressure $(0.4 \mathrm{~atm}$ at laboratory temperature) allowed incubation of the desiccators at temperatures up to $70^{\circ} \mathrm{C}$ without displacing the cover. For heterotrophic growth, an appropriate organic carbon source was added and cultures were incubated under air. If required, Oxoid agar no. $1\left(10 \mathrm{~g} \mathrm{l}^{-1}\right)$ was added. Stock cultures were maintained autotrophically on mineral agar slants and were transferred to fresh medium every 3 months.

Liquid cultures were grown in $100 \mathrm{ml}$ screw-capped Pyrex bottles containing $20 \mathrm{ml}$ medium; they were not agitated as this inhibited growth. Growth was followed turbidimetrically at $436 \mathrm{~nm}$, using $1 \mathrm{~cm}$ cuvettes in a Zeiss PM4 spectrophotometer.

To measure growth rates at different $\mathrm{pH}$ values, the $\mathrm{pH}$ of the medium was modified with either $\mathrm{NaOH}$ or $\mathrm{HCl}$. The exact $\mathrm{pH}$ value was then measured in control media after sterilization.

Nutritional characteristics. The utilization of compounds as sole sources of carbon and energy was tested in liquid media supplemented with carbohydrates $\left(2 \mathrm{~g} \mathrm{l}^{-1}\right)$, phenol $\left(0 \cdot 1 \mathrm{~g} \mathrm{l}^{-1}\right)$ or one of a number of the other carbon compounds $\left(\mathrm{g}^{-1}\right)$. A control lacking any carbon source was also inoculated.

The utilization of compounds as sole nitrogen sources was tested in liquid media, under autotrophic conditions. The medium used was the basal mineral medium without $\mathrm{NH}_{4} \mathrm{Cl}$, but supplemented with either $\mathrm{NaNO}_{2}\left(0.2 \mathrm{~g}^{-1}\right)$ or one of the other nitrogen compounds examined $\left(1 \mathrm{~g}^{-1}\right)$. Control cultures contained $\mathrm{NH}_{4} \mathrm{Cl}\left(\mathrm{g} \mathrm{l}^{-1}\right)$. Ability to fix $\mathrm{N}_{2}$ was tested using acetylene reduction to ethylene by nitrogenase; this was done under autotrophic conditions with reduced oxygen partial pressure $\left(p_{\mathrm{O}_{2}} 0.02 \mathrm{~atm}\right)$ in nitrogen-free medium.

Biochemical characteristics. Unless stated otherwise, the following tests were performed in liquid cultures, as described above, with basal mineral medium supplemented with sodium acetate at $1 \mathrm{~g}^{-1}$ (MMA). Cultures were incubated for 1 week at $65^{\circ} \mathrm{C}$ under air. Uninoculated media were used as controls.

MMA supplemented with appropriate substrates was employed for the following determinations. (i) Aerobic nitrate reduction and anaerobic growth in the presence of $\mathrm{KNO}_{3}\left(2 \mathrm{~g}^{-1}\right)$; nitrites were detected with the Griess reagent and an inverted Durham vial was used to detect gaseous nitrogen evolution. (ii) Indole formation from Tryptone $\left(1 \mathrm{~g}^{-1}\right.$; Difco), detected by production of a red colour with acidic p-dimethylaminobenzaldehyde. (iii) $\mathrm{H}_{2} \mathrm{~S}$ production from cysteine $\left(1 \mathrm{~g}^{-1}\right)$, detected by reaction with lead acetate strips suspended above the medium. (iv) Visible growth within 2 weeks in the presence of glycine $\left(10 \mathrm{~g}^{-1}\right)$ or $\mathrm{NaCl}\left(10,30,50\right.$ or $\left.70 \mathrm{~g}^{-1}\right)$; MMA without additions was used as a control. (v) Hydrolysis of soluble starch $\left(2 \mathrm{~g}^{-1}\right)$, tested with iodine reagent. (vi) Hydrolysis of gelatin; after 1 week incubation, MMA cultures containing gelatin $\left(60 \mathrm{~g}^{-1}\right), \mathrm{pH} 7 \cdot 2$, were chilled for detection of liquefaction.

Hydrolysis of casein was tested in Petri dishes containing solidified MMA supplemented with skim milk $\left(10 \mathrm{~g}^{-1}\right)$. The oxidase test was performed by adding $\alpha$-naphthol and $N, N$-dimethyl-p-phenylenediamine dihydrochloride $(1 \%, \mathrm{w} / \mathrm{v})$ directly to $48 \mathrm{~h}$-old MMA cultures. To test for catalase, 5 drops of $3 \%(\mathrm{v} / \mathrm{v})$ $\mathrm{H}_{2} \mathrm{O}_{2}$ were added to $48 \mathrm{~h}$-old MMA and autotrophic agar slant cultures.

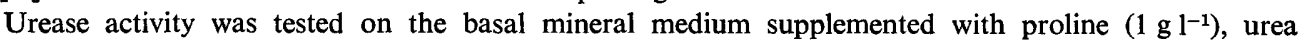
$\left(20 \mathrm{~g}^{-1}\right)$ and phenol red $\left(0.01 \mathrm{~g}^{-1}\right)$, $\mathrm{pH} 6.8$; this medium was sterilized by filtration. Urea was slowly hydrolysed at the incubation temperature, so controls lacking urea as well as uninoculated media were used. 
Penicillin susceptibility was tested on MMA containing 0.015 to 15.90 units (U) penicillin $\mathrm{G} \mathrm{ml}^{-1}$, as described by Wallhäusser \& Schmidt (1967). MMA without additions was used as a control. Cultures were incubated for 2 weeks.

Protein determination. The biuret method as described by Schmidt et al. (1963) was used, with bovine serum albumin as a standard.

Preparation of cell-free extracts. Cells were washed, suspended in $50 \mathrm{mM}$-phosphate buffer (final density about $10 \mathrm{mg}$ protein $\mathrm{ml}^{-1}$ ) and disintegrated by passage through a Sorvall $\mathrm{RM}$ cell fractionator at $100 \mathrm{MPa}$. Intact cells and debris were removed by centrifugation at $10000 \mathrm{~g}$ for $30 \mathrm{~min}$. The supernatant cell-free extract was used for further assays.

Enzyme tests. Hydrogenase [with either methylene blue or NAD(P) as electron acceptors], malate dehydrogenase and NADH oxidase were tested at $50^{\circ} \mathrm{C}$ as previously described (Aragno \& Schlegel, 1978b).

DNA base composition. The base composition was determined from the buoyant density in $\mathrm{CsCl}$ according to the procedure of Schildkraut et al. (1962). Micrococcus lysodeikticus DNA (density $1.731 \mathrm{~g} \mathrm{ml}^{-1}$ ) was used as a standard.

Poly- $\beta$-hydroxybutyrate. Attempts to isolate and identify poly- $\beta$-hydroxybutyrate were made by the method of Law \& Slepecky, as described in Herbert et al. (1971). Cells of Aquaspirillum autotrophicum, known to possess inclusions of poly- $\beta$-hydroxybutyrate (Aragno \& Schlegel, 1978 a), were used as a positive control.

Glycogen. The presence of glycogen in the cells was demonstrated by the method of Palmstierna, as described in Herbert et al. (1971). The precipitated glycogen was determined by the anthrone reagent.

Electron microscopy. Autotrophically grown cells were centrifuged $(4000 \mathrm{~g}, 5 \mathrm{~min})$ and washed three times in cacodylate buffer $(\mathrm{pH} 6 \cdot 0,0 \cdot 2 \mathrm{M})$. Fixation was done at laboratory temperature as described by Lickfeld (1976). Cells were pre-fixed with $5 \%(\mathrm{v} / \mathrm{v})$ glutaraldehyde in cacodylate buffer $(\mathrm{pH} 6 \cdot 0,0.2 \mathrm{M})$ for $2.5 \mathrm{~h}$ and then washed twice in RK buffer (pH 6.1) (Ryter \& Kellenberger, 1958). The main fixation was with $1 \%(\mathrm{w} / \mathrm{v}) \mathrm{OsO}_{4}$ in $\mathrm{RK}$ buffer $(\mathrm{pH} 6 \cdot 1)$ for $13 \mathrm{~h}(0.1 \mathrm{ml}$ freshly prepared Difco Bacto Tryptone B123 was added). Cells were then washed twice in RK buffer and embedded in $2 \%(\mathrm{w} / \mathrm{v})$ agar (Oxoid no. 1) at $47^{\circ} \mathrm{C}$ before post-fixation with $4 \%$ (w/v) uranyl acetate in RK buffer for $3 \mathrm{~h}$. After dehydration in a graded series of acetone/water mixtures, fixed cells were embedded in TAAB embedding resin. Ultrathin sections were cut using a Sorvall Porter Blum MT2B ultramicrotome with diamond knife. Sections were collected on copper grids and post-stained with uranyl acetate (saturated in $50 \%$ ethanol) for 10 min and lead citrate for $10 \mathrm{~min}$. Electron micrographs were taken with a Philips EM201 electron microscope operating at $80 \mathrm{kV}$.

\section{RESULTS AND DISCUSSION}

\section{Cultural characteristics}

The two representative strains chosen for this study formed different types of colonies: those of MA48 were smooth, circular and convex; those of MA51 were rough, flat and spreading. Except for this feature, both strains were similar.

Dense, uniformly turbid growth occurred in liquid synthetic media, under either autotrophic or heterotrophic conditions. Shaking the cultures strongly inhibited growth.

\section{Micromorphology}

The cell wall of strain MA48 had a three-layered structure as seen in electron micrographs of thin sections (Fig. 1). The central layer was densely stained, whereas the inner layer, adjacent to the cytoplasmic membrane, and the outer layer were less dense. In many sections, the outer and inner layers appeared to be composed of regularly spaced globular units, with a centre-to-centre spacing between the units of approximately $9 \mathrm{~nm}$.

A layered wall structure is not common among endospore-forming bacteria, though a similar type of wall has recently been found in three Gram-variable bacilli and in two Gram-variable clostridia (see Leduc et al., 1977, for a review). The three-layered wall structure of the hydrogen-oxidizing Bacillus is similar to the structure found in Bacillus sp. C.I.P. 76-111 (Leduc et al., 1977), in which a thin dense layer is sandwiched between two less dense layers.

In Bacillus sp. C.I.P. 76-111, as in the other organisms possessing such a multilayered wall, the thin dense layer corresponds to the peptidoglycan layer, while the less dense layers are made of protein subunits. Furthermore, all these bacteria possess a regular surface 


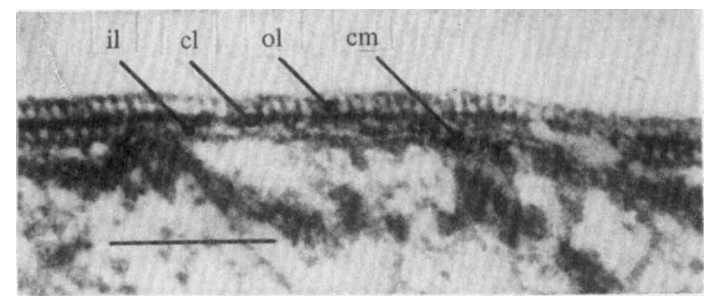

Fig. 1. Multilayered cell wall of strain MA48 showing regularly spaced globular units: cl, central layer; ol, outer layer; il, inner layer; $\mathrm{cm}$, cytoplasmic membrane. Bar marker represents $0 \cdot 1 \mu \mathrm{m}$.

pattern of subunits. We assume that the wall of strain MA48 is similar, but this needs further investigation. The wall composition and surface structure of the cell are now under study in our laboratory.

Neither mesosomes nor other intracytoplasmic membranes could be seen, except for membranes involved in septum and spore formation.

The only cytoplasmic inclusions observed were large electron-dense bodies, often in contact with cell membranes. A polysaccharide was isolated from autotrophically grown cells harvested in stationary phase; its anthrone spectrum was characteristic for glucose and so we assume that these inclusions consist of a glycogen-like glucan. In contrast to all Gram-negative, hydrogen-oxidizing bacteria investigated so far (Walther-Mauruschat et al., 1977), no poly- $\beta$-hydroxybutyrate could be detected.

\section{General properties}

Compared with other hydrogen-oxidizing bacteria (Aragno \& Schlegel, 1980), the organism used only a limited spectrum of organic chemicals as carbon and energy sources. Furthermore, autotrophic growth was much faster than heterotrophic growth (Aragno, 1978). Of 62 compounds tested with $\mathrm{NH}_{4} \mathrm{Cl}$ as sole nitrogen source, the following substances were used as carbon and energy sources: acetate, butyrate, caproate, fumarate, DL- $\beta$ hydroxybutyrate, L-malate, propionate, pyruvate, succinate, valerate, L-alanine, L-cysteine, L-glutamate, L-phenylalanine, L-proline, phenol and 1-propanol; growth with phenol occurred only at concentrations up to $1 \mathrm{~g}^{-1}$. The following substances were not used: benzoate, citrate, formate, gluconate, glycollate, $p$-hydroxybenzoate, $\alpha$-ketoglutarate, DLlactate, malonate, mesaconate, $\mathrm{D}(-)$-tartrate, $\mathrm{L}(+)$-tartrate, meso-tartrate, L-arginine, Lasparagine, L-aspartate, L-citrulline, L-glutamine, glycine, L-histidine, L-isoleucine, L-leucine, L-lysine, L-methionine, L-ornithine, L-serine, L-tryptophan, L-valine, L-arabinose, cellobiose, D-fructose, D-galactose, D-glucose, D-maltose, D-mannose, L-rhamnose, saccharose, Lsorbose, trehalose, D-xylose, 1-butanol, ethanol, glycerol, mannitol and methanol.

Ammonium salts, asparagine and urea were used as sole nitrogen sources in autotrophic cultures; nitrates, nitrites and molecular nitrogen were not.

The biochemical properties of the two strains, together with their temperature and pH optima for growth, penicillin susceptibility and DNA base composition, are summarized in Table 1.

For most aerobic spore-formers, the $\mathrm{G}+\mathrm{C}$ content of their DNA is between 32 and $53 \mathrm{~mol} \%$. Strains MA48 and MA51 have a much higher $\mathrm{G}+\mathrm{C}$ content, approaching that of the recently described thermophilic bacilli, i.e. B. acidocaldarius $(62 \mathrm{~mol} \% \mathrm{G}+\mathrm{C}$; Darland \& Brock, 1971), B. thermoruber (67 mol \% G+C; Guicciardi et al., 1968), and $B$. thermocatenulatus (69 mol \% G+C; Golovacheva et al., 1975).

\section{Penicillin susceptibility}

While controls without penicillin showed growth after $2 \mathrm{~d}$, growth did not occur until $4 \mathrm{~d}$ in the presence of $0.015 \mathrm{U}$ penicillin $\mathrm{G} \mathrm{ml}^{-1}$ and $12 \mathrm{~d}$ in the presence of $15.90 \mathrm{U}$ penicillin $\mathrm{G} \mathrm{ml}^{-1}$. To test whether the growth lags were due to heat destruction of the 
Table 1. Biochemical characteristics and other general properties

of the hydrogen-oxidizing Bacillus

Character

Nitrate reduction to nitrite

$\mathrm{N}_{2}$ evolution from nitrate

Oxidase

Catalase

Urease

Hydrolysis of gelatin

Hydrolysis of casein

Hydrolysis of starch

Indole formation

$\mathrm{H}_{2} \mathrm{~S}$ from cysteine

Growth in the presence of $1 \%(\mathrm{w} / \mathrm{v})$ glycine

Growth in the presence of $3 \%(w / v) ~ N a C l$

Growth in the presence of $5 \%(\mathrm{w} / \mathrm{v}) \mathrm{NaCl}$

Optimum temperature (autotrophic growth, $\mathrm{pH} 7 \cdot 0$ )

Optimum $\mathrm{pH}$ (growth on $\mathrm{MMA}, 65^{\circ} \mathrm{C}$ )

M.i.c. of penicillin $\mathbf{G}$

DNA base composition: strain MA48 strain MA51

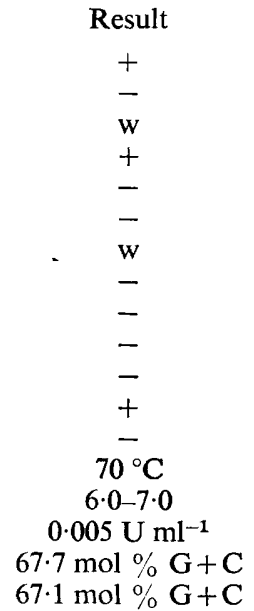

+ , Positive; w, weakly positive; - , negative.

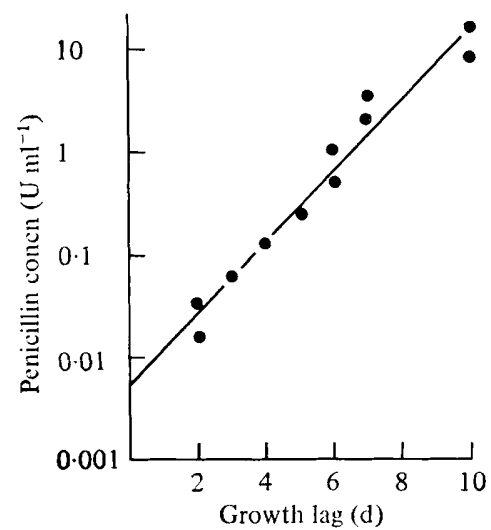

Fig. 2. Relation between growth lag (compared with a control) and the initial concentration of penicillin $\mathrm{G}$ in the medium (semilogarithmic plot). Incubation temperature was $65^{\circ} \mathrm{C}$.

antibiotic, MMA containing $15.90 \mathrm{U}$ penicillin $\mathrm{G} \mathrm{ml}^{-1}$ was incubated for $14 \mathrm{~d}$ at $65^{\circ} \mathrm{C}$ before inoculation. In these media, growth was as rapid as in a control without penicillin G. There was an almost linear relationship between the logarithm of penicillin $G$ concentration and growth lag as compared with the control (Fig. 2); this corresponds to the heat destruction curve of the antibiotic at $65^{\circ} \mathrm{C}$. From the intercept of the curve with the ordinate, the minimum inhibitory concentration (m.i.c.) of penicillin $\mathrm{G}$ was about $0.005 \mathrm{U}$ $\mathrm{ml}^{-1}$, which is very low compared with other Gram-positive bacteria.

\section{Hydrogenase activity}

Crude cell-free extracts of autotrophically grown cells contained hydrogenase activity, measured manometrically under $100 \% \mathrm{H}_{2}$ with methylene blue as electron acceptor, comparable to that of intact cells [1969 versus $2207 \mathrm{nmol} \mathrm{H}_{2} \mathrm{~min}^{-1}$ (mg protein)-1]. No activity was detected using either NAD or NADP as potential electron acceptors (tested photometrically). After centrifuging the cell-free extract at $140000 \mathrm{~g}$ for $2 \mathrm{~h}$, the supernatant and sediment (particulate fraction) were both tested for hydrogenase activity, and for activities of malate dehydrogenase (a soluble enzyme) and NADH oxidase (a membrane- 
Table 2. Distribution of hydrogenase, malate dehydrogenase and NADH oxidase activities between particulate and soluble fractions of cell-free extract

The soluble and particulate fractions were obtained by centrifuging the cell-free extract for $2 \mathrm{~h}$ at $140000 \mathrm{~g}$. Enzyme activities in these fractions are expressed as a percentage of the activities in the cell-free extract.

\begin{tabular}{|c|c|c|c|}
\hline & Hydrogenase* & $\begin{array}{c}\text { Malate } \\
\text { dehydrogenase }\end{array}$ & NADH oxidase \\
\hline Cell-free extract & 100 & 100 & 100 \\
\hline Soluble fraction & 15 & 100 & 7 \\
\hline Particulate fraction & 72 & 8 & 78 \\
\hline
\end{tabular}

bound activity). The results (Table 2) show that most of the hydrogenase activity was in the particulate fraction, i.e. a membrane-bound, non-NAD-reducing hydrogenase was present, but no cytoplasmic NAD-reducing hydrogen-dehydrogenase could be detected. This appears to be the most common pattern in hydrogen-oxidizing bacteria (Schneider \& Schlegel, 1977).

\section{Autotrophic growth of other bacilli}

Other bacilli possessing characteristics in common with strains MA48 and MA51 were tested for autotrophic growth under $\mathrm{H}_{2} / \mathrm{O}_{2} / \mathrm{CO}_{2}$ at their respective temperature and $\mathrm{pH}$ optima. These included thermophilic strains of Bacillus sphaericus (Hollaus \& Klaushofer, 1970 ) as well as mesophilic strains of the same species previously attributed to B. pycnoticus (R. E. Gordon, personal communication), B. thermoruber (Guicciardi et al., 1968; Aragozzini et al., 1976) and B. acidocaldarius (Darland \& Brock, 1971). None of these strains were able to develop autotrophically.

\section{Proposal of a new species}

The characteristics of strains MA48 and MA51 fit the description of the genus Bacillus as defined in the 8th edition of Bergey's Manual (Buchanan \& Gibbons, 1974), i.e. aerobic, rod-shaped cells with peritrichous flagellation, forming one endospore per cell. In Table 3, the characteristics of strains MA48 and MA51 are compared with those of Bacillus sphaericus and with those of the other thermophilic bacilli with high $\mathrm{G}+\mathrm{C}$ content of DNA. The much higher $\mathrm{G}+\mathrm{C}$ content of strains MA48 and MA51 excludes any affinity with $B$. sphaericus; these two strains also differ considerably from other bacilli having a high $\mathrm{G}+\mathrm{C}$ content, e.g. in spore shape, inability to grow on sugars, ability to develop autotrophically under $\mathrm{H}_{2} / \mathrm{O}_{2} / \mathrm{CO}_{2}$, and so on. Strains MA48 and MA51 also differ from B. pycnoticus as described by Grohmann (1924); this bacterium has cylindrical spores (not formed under autotrophic conditions) and is able to use carbohydrates as carbon and energy sources. Thus, we consider that strains MA48 and MA51 represent a new species, for which we propose the name Bacillus schlegelii. We dedicate this new species to Professor Hans G. Schlegel, Director of the Institute of Microbiology of the University of Göttingen, Federal Republic of Germany.

\section{Description of the species}

Bacillus schlegelii sp.nov.

schle.gel'i.i. M.L. gen.n. schlegelii of Schlegel; named after H. G. Schlegel, a German microbiologist.

Long, straight, rod-shaped cells, $0.6 \mu \mathrm{m} \times 2.5$ to $5 \mu \mathrm{m}$, with peritrichous flagellation; spherical, terminal endospores formed, 0.8 to $1 \mu \mathrm{m}$ in diameter, distinctly distending the sporangium. Gram-variable.

Colonies cream-coloured, round or spreading over the agar surface. Neither a carotenoid pigment nor poly- $\beta$-hydroxybutyrate are produced. 
Table 3. Characteristics useful for differentiating between strains MA48 and MA51 and other thermophilic bacilli

\begin{tabular}{|c|c|c|c|c|c|}
\hline Character & MA48, MA51 & $\begin{array}{c}\text { B. } \\
\text { sphaericus }\end{array}$ & $\begin{array}{c}B . \\
\text { acidocaldarius }\end{array}$ & $\begin{array}{c}B . \\
\text { thermoruber }\end{array}$ & $\begin{array}{l}\text { B. thermo- } \\
\text { catenulatus }\end{array}$ \\
\hline $\mathrm{G}+\mathrm{C}(\mathrm{mol} \%)$ & $67-68$ & $37-43$ & $61-62$ & 67 & 69 \\
\hline Spore shape* & $\mathrm{S}$ & $\mathbf{S}$ & $\mathrm{o}$ & $\mathrm{O}$ & $\mathrm{O}$ \\
\hline Gram-reaction & $\mathrm{v}$ & $\mathrm{v}$ & $\mathrm{v}$ & $\mathrm{v}$ & + \\
\hline Motility & + & + & & + & + \\
\hline Optimum pH & $6-7$ & neutral & $2-5 / 6$ & neutral & neutral \\
\hline Optimum temperature $\left({ }^{\circ} \mathrm{C}\right)$ & 70 & $30 \dagger$ & 65 & $45-50$ & $55-70$ \\
\hline $\mathrm{H}_{2}$ autotrophy & + & - & - & - & . \\
\hline Pigment & - & - & - & + & - \\
\hline Auxotrophy & - & + & - & + & - \\
\hline Facultatively anaerobic & - & - & - & - & + \\
\hline Poly- $\beta$-hydroxybutyrate & - & . & . & . & + \\
\hline \multicolumn{6}{|l|}{ Carbon and energy sources: } \\
\hline Acetate & + & . & - & . & . \\
\hline Citrate & - & . & - & . & + \\
\hline D-Gluconate & - & . & + & . & . \\
\hline Succinate & + & . & - & . & . \\
\hline Sugars (at least some) & - & - & + & . & + \\
\hline Glycerol & - & + & + & . & + \\
\hline Mannitol & - & - & . & . & + \\
\hline \multicolumn{6}{|l|}{ Nitrogen sources: } \\
\hline Ammonium & + & . & + & - & . \\
\hline Nitrate & - & . & - & - & . \\
\hline Urea & + & . & . & - & \\
\hline Nitrate reduction & $\mathrm{NO}_{2}^{-}$ & - & . & . & $\mathrm{N}_{2}$ \\
\hline Nitrate respiration & - & - & - & . & + \\
\hline Urease & - & + & . & . & - \\
\hline Hydrolysis of starch & - & - & + & $\mathrm{w}$ & - \\
\hline Hydrolysis of gelatin & - & $\mathrm{v}$ & . & ++ & - \\
\hline Hydrolysis of casein & $\mathrm{w}$ & $\mathrm{v}$ & . & ++ & w \\
\hline Penicillin $\mathrm{G}$ (m.i.c., $\mathrm{U} \mathrm{ml}^{-1}$ ) & 0.005 & - & . & 8 & 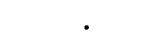 \\
\hline
\end{tabular}

No growth factors required.

Strictly respiratory metabolism, with oxygen as the terminal electron acceptor. Cannot grow anaerobically with nitrate. Nitrate reduced to nitrite.

Either chemolithoautotrophic, using $\mathrm{H}_{2}$ as the electron donor and $\mathrm{CO}_{2}$ as the carbon source, or chemoorganoheterotrophic.

Phenol, 1-propanol and a small number of amino acids and organic acids can serve as sole carbon sources, with ammonium ions as the nitrogen source. Sugars not metabolized. Ammonium ions, urea and asparagine can be utilized as sole nitrogen sources.

Hydrogenase constitutive, membrane-bound, and not NAD(P) specific; hydrogenase activity strongly thermophilic, with a temperature optimum between 70 and $75^{\circ} \mathrm{C}$. Catalase and oxidase positive. Urease not produced. Weak hydrolysis of casein. No hydrolysis of starch and gelatin. $\mathrm{H}_{2} \mathrm{~S}$ not produced from cysteine. Indole not produced. Growth in the presence of $3 \% \mathrm{NaCl}$, but not $5 \%$. No growth in the presence of $1 \%$ glycine. Minimum inhibitory penicillin $\mathrm{G}$ concentration: $0.005 \mathrm{U} \mathrm{ml}^{-1}$.

Temperature for optimum growth about $70{ }^{\circ} \mathrm{C}$; no growth at 37 or $80^{\circ} \mathrm{C}$. pH for optimum growth 6 to 7 .

The $\mathrm{G}+\mathrm{C}$ content of the DNA is 67 to $68 \mathrm{~mol} \%$.

Isolated from the surface layer of the sediment of a small eutrophic lake near Neuchâtel, Switzerland. 
Type strain: strain MA48 is designated as the type strain for the species. It has been deposited with the Deutsche Sammlung von Mikroorganismen, Göttingen, F.R.G., under the accession number 2000. The description of the type strain is the same as that given above for the species with the following addition: the $\mathrm{G}+\mathrm{C}$ content of the DNA is $67.7 \mathrm{~mol} \%$.

The authors are indebted to Professor H. G. Schlegel, who has helped us greatly with his constant interest, suggestions and encouragement. We would like to thank Drs R. E. Gordon, D. Claus, F. Hollaus and R. Craveri for their interest and for providing us with strains. The help of J. Keller for the electron microscopy and of B. Jenni in determining the DNA characteristics is gratefully acknowledged. The analytical ultracentrifuge was kindly made available by the Institute of Molecular Biology, University of Geneva. We are grateful to Dr Helen Stoeckli-Evans who reviewed our manuscript.

\section{REFERENCES}

Allen, M. B. (1953). The thermophilic aerobic spore-forming bacteria. Bacteriological Reviews 17, 125-173.

Aragno, M. (1978). Enrichment, isolation and preliminary characterization of a thermophilic, endospore-forming hydrogen bacterium. FEMS Microbiology Letters 3, 13-15.

Aragno, M. \& Schlegel, H. G. (1978a). Aquaspirillum autotrophicum, a new species of hydrogen-oxidizing, facultatively autotrophic bacteria. International Journal of Systematic Bacteriology 28, 112-116.

Aragno, M. \& Schlegel, H. G. (1978b). Physiological characterization of the hydrogen bacterium Aquaspirillum autotrophicum. Archives of Microbiology 116, 221-229.

Aragno, M. \& Schlegel, H. G. (1980). The hydrogen-oxidizing bacteria. In The Prokaryotes: a Handbook on Habitats, Isolation and Identification of Bacteria. Edited by M. P. Starr, H. Stolp, H. G. Trüper, A. Balows \& H. G. Schlegel. Berlin, Heidelberg \& New York: Springer-Verlag.

Aragno, M., Walther-Mauruschat, A., Mayer, F. \& SCHLEGEL, H. G. (1977). Micromorphology of Gram-negative hydrogen bacteria. I. Cell morphology and flagellation. Archives of Microbiology 114, 93-100.

Aragozzini, F., Toppino, P., Manachini, P. L. \& Craveri, R. (1976). Fatty acid composition of Bacillus thermoruber. Annali di microbiologia ed enzimologia 26, 9-13.

Buchanan, R. E. \& Gibbons, N. E. (editors) (1974). Bergey's Manual of Determinative Bacteriology, 8th edn. Baltimore: Williams \& Wilkins.

Darland, G. \& Brock, T. D. (1971). Bacillus acidocaldarius sp.nov., an acidophilic thermophilic spore-forming bacterium. Journal of General Microbiology 67, 9-15.

Davis; D. H., Doudoroff, M., Stanier, R. Y. \& MandeI, M. (1969). Proposal to reject the genus Hydrogenomonas. Taxonomic implications. International Journal of Systematic Bacteriology 19, 375-390.

Davis, D. H., Stanier, R. Y., Doudoroff, M. \& MANDEL, M. (1970). Taxonomic studies on some Gram-negative polarly flagellated 'hydrogen

bacteria' and related species. Archiv für Mikrobiologie 70, 1-13.

EBERHARDT, U. (1965). Die Anreicherung von Knallgasbakterien. In Anreicherungskultur und Mutantenauslese, pp. 155-169. Edited by H. G. Schlegel \& E. Kröger. Stuttgart: G. Fischer Verlag. Golovacheva, R. S., Loginova, L. G., Salikhov, - T. A., Kolesnikov, A. A. \& Zaitseva, G. N. (1975). A new thermophilic species, Bacillus thermocatenulatus, nov.sp. Mikrobiologiya 44, 265-266.

GrohmanN, G. (1924). Zur Kenntnis Wasserstoff oxydierender Bakterien. Zentralblatt für Bakteriologie, Parasitenkunde, Infektionskrankheiten und Hygiene (Abteilung II) 61, 256-271.

Guicciardi, A., BIfFi, M. R., Manachini, P. L., Craveri, A., Scolastico, C., Rindone, B. \& Craveri, R. (1968). Ricerche preliminari su un nuovo schizomicete termofilo del genere Bacillus e caratterizzazione del pigmento rosso prodotto. Annali di microbiologia ed enzimologia 18, 191-205.

Herbert, D., Phipps, P. J. \& Strange, R. E. (1971). Chemical analysis of microbial cells. Methods in Microbiology 5B, 209-344.

Hollaus, F. \& Klaushofer, H. (1970). Taxonomische Untersuchungen an hochtermophilen Bacillus-Stämmen aus Zuckerfabrikssäften. Publications of the Faculty of Sciences of the University J. G. Purkyne, Brno 47, 99-105.

Leduc, M., Rousseau, M. \& van Heijenoort, J. (1977). Structure of the cell wall of Bacillus species C.I.P. 76-111. European Journal of Biochemistry 80, 153-163.

LiCKFELD, K. G. (1976). Transmission electron microscopy of bacteria. Methods in Microbiology 9, 127-176.

PfenNig, N. \& Lippert, K. D. (1966). Über das Vitamin- $\mathrm{B}_{12}$-Bedürfnis phototropher Schwefelbakterien. Archiv für Mikrobiologie 55, 245-256.

RuHLAND, W. (1922). Aktivierung von Wasserstoff und Kohlensäure-Assimilation durch Bakterien. Berichte der Deutschen botanischen Gesellschaft 40, 180-184.

Ruhland, W. (1924). Beiträge zur Physiologie der Knallgasbakterien. Jahrbücher für wissenschaftliche Botanik 63, 321-389. 
Ryter, A. \& Kellenberger, E. (1958). Étude au microscope électronique de plasma contenant de l'acide désoxyribonucléique. I. Les nucléotides des bactéries en croissance active. Zeitschrift für Naturforschung 13b, 597-605.

Schildkraut, C. L., Marmur, J. \& Doty, P. (1962). Determination of the base composition of deoxyribonucleic acid from its buoyant density in CsCl. Journal of Molecular Biology 4, 430-443.

Schlegel, H. G., Kaltwasser, H. \& Gottschalk, G. (1961). Ein Submersverfahren zur Kultur wasserstoffoxydierender Bakterien: Wachstumsphysiologische Untersuchungen. Archiv für Mikrobiologie 38, 209-222.

SchmidT, K., LiaAen-Jensen, S. \& Schlegel, H. G. (1963). Die Carotinoide der Thiorhodaceae. Archiv für Mikrobiologie 46, 117-126.
Schneider, K. \& Schlegel, H. G. (1977). Localization and stability of hydrogenases from aerobic hydrogen bacteria. Archives of Microbiology 112, 229-238.

WAllhäUSSER, K. H. \& SCHMidT, H. (1967). Sterilisation, Desinfektion, Konservierung, Chemotherapie, pp. 420-421. Stuttgart: G. Thieme Verlag.

Walther-Mauruschat, A., Aragno, M., Mayer, F. \& Schlegel, H. G. (1977). Micromorphology of Gram-negative hydrogen bacteria. II. Cell envelope, membranes and cytoplasmic inclusions. Archives of Microbiology 114, 101-110.

WILDE, E. (1962). Untersuchungen über Wachstum und Speicherstoffsynthese von Hydrogenomonas. Archiv für Mikrobiologie 107, 139-142. 